\title{
Occurrence and Abundance of Cyanobacterial Strains and Physico-chemical Properties of Water Bodies
}

\author{
Ankita Lal and Suchit John* \\ Department of Biological Sciences, SHUATS, Prayagraj, India \\ *Corresponding author
}

Key w o r d s
Cyanobacterial
population,
Physico-chemical
properties,
Cyanobacterial
distribution, algal
distribution

\section{A B S T R A C T}

The current work was involved in the occurrence and abundance of the cyanobacteria strains present in the predominant water outlets present in the city Prayagraj, for analysing the types of strains found during the different seasonal interims. The cyanobacteria distribution in water from water samples are collected from above mentioned locations during the January, May and September months in the year of 2013 and 2014. The cyanobacteria population in the vicinity was analyzed using the physico-chemical factors like $\mathrm{pH}$, temperature, electrical conductivity, total phosphorus, inorganic phosphorus, ammoniacal nitrogen, nitrate, nitrite, iron, zinc, Manganese, Copper and arsenic and algal flora (qualitative) were also studied and compared their variations among the three different freshwater bodies. In addition, biological parameters such as primary production gross primary productivity, net primary productivity and community respiration rate were also studied. Total 11 species of cyanobacteria were isolated. It was observed that the distributional patterns of the cyanobacteria were related with that of the physico-chemical parameters of the water sample. Since there was no significant difference in the parameters of the sampling sites, a few cyanobacterial strains were found to be dominating, followed by co-dominating and peripheral species which were found to be common in all the sampling sites. This ultimately shows that there is no significant change in the distribution of the cyanobacterial strains in the current area of study under the same equatorial region.

\section{Introduction}

Cyanobacteria also known as the blue-green algae, Cyanoprokayotes, Cyanophytes are an ancient group of photosynthetic microorganisms which occur in aquatic bodies and that can have major effects on the water quality and functioning of aquatic ecosystems. They include about 2000 species in 150 genera, with a wide range of shapes and sizes. Cyanobacteria have a variety of cell types, cellular structures, and physiological strategies that contribute to their ecological success in the plankton, metaphyton, or periphyton. Cyanobacteria are aquatic and photosynthetic prokaryotes, which possess mainly chlorophyll- $a$. Cyanobacteria are of special interest to water quality managers because many produce taste and odour compounds, several types of toxins, and noxious blooms. Ecologically, the three most important groups of cyanobacteria found in 
inland waters are mat-formers, which form polysaccharide-rich crusts, films, and thicker layers over rocks, sediments, and plants; bloom-formers, which occur in eutrophic lakes and cause food web disruption as well as produce toxins and surface scums; and picocyanobacteria, minute species that are often the main photosynthetic cell type in oligotrophic (nutrient-poor) lakes and their microbial food webs. Considering the economic importance of cyanobacteria is very large in both negative and positive senses. In negative side, many cyanobacterial strains appear to be toxic blooms, cause harmful significance to livestock and human life. In contrast, cyanobacteria are also having an increasingly positive economic importance, forming the basis of new food industries and their widely use as biofertilizers in agriculture. Cyanobacteria produce secondary metabolites with diverse chemical structures and biological activities of industrial and pharmaceutical interest. The secondary metabolites of cyanobacteria are produced during the life cycle. Many of the industrially important antibiotics and secondary metabolites produced by different species have been well studied; therefore by isolating cyanobacteria from an environment such as nearby river Yamina of Prayagraj district have the potential of discovering novel secondary metabolites of industrial significance is increased. Cyanobacteria play an important role in the rhizosphere region where they influence plant growth and protect plant roots against invasion by pathogenic fungi. Cyanobacterial populations are reported to inhabit diverse aquatic environments like nutrient rich lakes, rivers ponds and others water sources. The vulnerability of cyanobacteria to environmental impact and their possible depletion or extinction like other microalgae necessitated the understanding of the distribution of cyanobacterial population in selected aquatic bodies which are important to economic, recreational and religious activity of people. It was also considered important to characterize cyanobacterial population in relation to physico-chemical parameters of water bodies.

\section{Materials and Methods}

Water samples are collected from above mentioned locations during the January, May and September months. The collected water samples from each aquatic site were subjected to physico-chemical analysis and also used for the isolation of cyanobacterial strains. Three aquatic sampling sites were identified for the collection of water samples. These aquatic bodies are located around Prayagraj district of Uttar Pradesh. Mainly the sampling sites are located nearby the SHUATS, campus (Table 1).

\section{Results and Discussion}

\section{Physico-chemical analysis of water samples}

Data presented in table 3 and figure 1 show that the value of $\mathrm{pH}$ in 2013 and in year 2014 is ranges between 6.9 to 8.3 and 6.96 to 8.23 respectively and found suitable for the growth of the blue green algae in the all sampling sites. Perusal of data also revealed that the $\mathrm{pH}$ exhibited positive and highly significant variation at different sites in year 2013 and 2014. The maximum $\mathrm{pH}$ value was recorded at siteS2 followed by siteS1and site S6 whereas minimum value was found at siteS5 in the both year (Table 2).

\section{Electrical conductivity (EC) (dS/m)}

It is a measure of material's ability to conduct electric current through it or in case of an aquatic sample, electrical conductivity means the total amount of solids dissolved in water which is also called ac TDS(Total Dissolved Solids). Data presented in table 4 and figure 2 
shows that the value of EC in 2013 and in year 2014 is ranges between 0.34 to 0.70 and 0.35 to 0.683 respectively and found suitable for the growth of the blue green algae in the all sampling sites. Perusal of data also revealed that the EC exhibited positive and highly significant variation at different sites in year 2013 and 2014. The maximum EC value was recorded at siteS1 followed by siteS2and site S5 whereas minimum value was found at siteS6 in the both year.

Table.1 Methodology used for the parameters studied in water samples

\begin{tabular}{|l|l|l|}
\hline Parameters & Methods for determination & \multicolumn{1}{c|}{ References } \\
\hline pH & pH meter & APHA, 2005 \\
\hline Electrical Conductivity & Conductivity meter & APHA, 2005 \\
\hline Nitrogen as Ammonia $\left(\mathbf{N H}_{\mathbf{3}}\right)$ & Nesselerization method & APHA, 2005 \\
\hline Nitrogen as Nitrites $\left(\mathbf{N O}_{\mathbf{2}}\right)$ & Spectrophotometer & APHA, 2005 \\
\hline Phosphorus $\left(\mathbf{P O}_{\mathbf{4}}\right)$ & Stannous chloride method & APHA, 2000 \\
\hline Heavy metals & AAS & Burell, 1975; Slavin, 1968 \\
\hline
\end{tabular}

Table.2 Occurrence and abundance of cyanobacterial strains with physico-chemical properties of water bodies

\begin{tabular}{|l|c|c|c|c|c|}
\hline Species & $\mathbf{p H}$ & $\boldsymbol{E C}$ & $\mathbf{N O}_{\mathbf{2}}$ & $\mathbf{N H}_{\mathbf{3}}$ & $\mathbf{P O}_{\mathbf{4}}$ \\
\hline Chalmydomonas & 0.09 & -0.42 & 0.07 & 0.29 & -0.31 \\
\hline Chlorella & 0.35 & 0.79 & 0.56 & 0.43 & 0.69 \\
\hline Volvox & 0.72 & 0.61 & 0.45 & 0.45 & 0.5 \\
\hline Nostoc & -0.08 & 0.16 & -0.14 & -0.17 & 0.29 \\
\hline Spirogyra & 0.17 & 0.001 & -0.29 & -0.2 & 0.14 \\
\hline Microcystis & 0.03 & 0.08 & 0.07 & -0.05 & -0.06 \\
\hline Anabaena & -0.1 & -0.21 & -0.41 & -0.34 & -0.02 \\
\hline Oedogonium & -0.16 & -0.33 & -0.57 & -0.44 & -0.18 \\
\hline Ulothrix & -0.22 & 0.15 & -0.37 & -0.44 & -0.11 \\
\hline $\begin{array}{l}\text { Anabaena } \\
\text { fertilissima }\end{array}$ & -0.71 & -0.49 & -0.26 & -0.45 & -0.53 \\
\hline Phormidium & 0.02 & -0.54 & -0.14 & 0.11 & -0.47 \\
\hline
\end{tabular}

Table.3 $\mathrm{pH}$ value of water samples collected from different study sites

\begin{tabular}{|l|c|c|}
\hline \multicolumn{1}{|c|}{ Sampling Site } & pH value 2013 & pH value 2014 \\
\hline Old Yamuna Bridge (Yamuna) & 7.3 & 7.2 \\
\hline Saraswati Ghat (Yamuna) & 8.3 & 8.2 \\
\hline College of Forestry (SHUATS) & 7.3 & 7.3 \\
\hline Naini Agriculture Institute (SHUATS) & 7.3 & 7.2 \\
\hline University Central Canteen) (SHUATS) & 6.9 & 6.9 \\
\hline Girls Hostel campus (SHUATS) & 7.3 & 7.2 \\
\hline C.D. & 0.29 & 0.37 \\
\hline SE(m) & 0.09 & 0.11 \\
\hline SE(d) & 0.13 & 0.16 \\
\hline
\end{tabular}


Table.4 EC (dS/m) value of water samples collected from different study sites

\begin{tabular}{|l|c|c|}
\hline \multicolumn{1}{|c|}{ Sampling Site } & $\mathbf{E C}(\mathbf{d S} / \mathbf{m})$ value 2013 & $\mathbf{E C}(\mathbf{d S} / \mathbf{m})$ value 2014 \\
\hline Old Yamuna Bridge (Yamuna) & 0.700 & 0.683 \\
\hline Saraswati Ghat (Yamuna) & 0.580 & 0.603 \\
\hline College of Forestry (SHUATS) & 0.390 & 0.423 \\
\hline Naini Agriculture Institute (SHUATS) & 0.420 & 0.427 \\
\hline University Central Canteen) (SHUATS) & 0.470 & 0.450 \\
\hline Girls Hostel campus (SHUATS) & 0.340 & 0.350 \\
\hline C.D. & 0.053 & 0.069 \\
\hline SE(m) & 0.016 & 0.021 \\
\hline SE(d) & 0.023 & 0.030 \\
\hline
\end{tabular}

Table.5 Availability of Nitrogen as Ammonia (ppm/L) in different water sample from different sites

\begin{tabular}{|l|c|c|}
\hline \multicolumn{1}{|c|}{ Sampling Site } & $\mathbf{2 0 1 3}$ & $\mathbf{2 0 1 4}$ \\
\hline Old Yamuna Bridge (Yamuna) $\mathbf{S}_{\mathbf{1}}$ & 39.200 & 39.267 \\
\hline Saraswati Ghat (Yamuna) $\mathbf{S}_{\mathbf{2}}$ & 28.400 & 27.300 \\
\hline College of Forestry (SHUATS) $\mathbf{S}_{\mathbf{3}}$ & 5.400 & 6.900 \\
\hline Naini Agriculture Institute (SHUATS) $\mathbf{S}_{\mathbf{4}}$ & 2.100 & 3.367 \\
\hline University Central Canteen) (SHUATS) $\mathbf{S}_{\mathbf{5}}$ & 1.800 & 2.567 \\
\hline Girls Hostel campus (SHUATS) $\mathbf{S}_{\mathbf{6}}$ & 19.400 & 18.333 \\
\hline C.D. & 1.730 & 3.239 \\
\hline SE(m) & 0.542 & 1.015 \\
\hline SE(d) & 0.766 & 1.435 \\
\hline
\end{tabular}

Table.6 Availability of Nitrogen as Nitrites $\left(\mathrm{NO}_{2}\right)$ in different water sample

\begin{tabular}{|l|c|c|}
\hline \multicolumn{1}{|c|}{ Sampling Site } & $\begin{array}{c}\text { Available N (mg/L) } \\
\mathbf{2 0 1 3}\end{array}$ & $\begin{array}{c}\text { Available N }(\mathbf{m g} / \mathbf{L}) \\
\mathbf{2 0 1 4}\end{array}$ \\
\hline Old Yamuna Bridge (Yamuna) $\mathbf{S}_{\mathbf{1}}$ & 5.700 & 5.433 \\
\hline Saraswati Ghat (Yamuna) $\mathbf{S}_{\mathbf{2}}$ & 3.500 & 3.567 \\
\hline College of Forestry (SHUATS) $\mathbf{S}_{\mathbf{3}}$ & 0.100 & 0.133 \\
\hline Naini Agriculture Institute (SHUATS) $\mathbf{S}_{\mathbf{4}}$ & 0.300 & 0.343 \\
\hline University Central Canteen) (SHUATS) $\mathbf{S}_{\mathbf{5}}$ & 0.800 & 0.797 \\
\hline Girls Hostel campus (SHUATS) $\mathbf{S}_{\mathbf{6}}$ & 1.300 & 2.033 \\
\hline C.D. & 0.429 & 0.751 \\
\hline SE(m) & 0.134 & 0.235 \\
\hline SE(d) & 0.190 & 0.333 \\
\hline
\end{tabular}


Table.7 Availability of Phosphorus as Phosphate $(\mathrm{mg} / \mathrm{L})$ in different water sample

\begin{tabular}{|l|c|c|c|}
\hline Sampling sites & $\mathbf{2 0 1 3}$ & $\mathbf{2 0 1 4}$ & Pooled \\
\hline Old Yamuna Bridge (Yamuna) & 0.38 & 0.42 & 0.40 \\
\hline Saraswati Ghat (Yamuna) & 0.42 & 0.49 & 0.455 \\
\hline College of Forestry (SHUATS) & 0.17 & 0.20 & 0.185 \\
\hline $\begin{array}{l}\text { Naini Agriculture Institute } \\
\text { (SHUATS) }\end{array}$ & 0.10 & 0.17 & 0.135 \\
\hline $\begin{array}{l}\text { University Central Canteen) } \\
\text { (SHUATS) }\end{array}$ & 0.02 & 0.09 & 0.55 \\
\hline Girls Hostel campus (SHUATS) & 1.40 & 1.42 & 1.41 \\
\hline
\end{tabular}

Table.8 Availability of Heavy metals in different water sample

\begin{tabular}{|c|c|c|c|c|c|c|c|c|c|c|c|c|c|c|}
\hline $\begin{array}{l}\text { Sampling } \\
\text { sites }\end{array}$ & \multicolumn{3}{|c|}{ Iron $(\mathrm{Fe})(\mathrm{mg} / \mathrm{l})$} & \multicolumn{3}{|c|}{$\begin{array}{c}\text { Copper } \\
(\mathrm{Cu})(\mathrm{mg} / \mathrm{l})\end{array}$} & \multicolumn{3}{|c|}{$\begin{array}{l}\text { Manganese } \\
(\mathrm{Mn})(\mathrm{mg} / \mathrm{l})\end{array}$} & \multicolumn{3}{|c|}{$\begin{array}{c}\text { Arsenic } \\
(\mathrm{As})(\mathrm{mg} / \mathrm{l})\end{array}$} & \multicolumn{2}{|c|}{$\begin{array}{c}\text { Zinc } \\
(\mathrm{Zn})(\mathrm{mg} / \mathrm{l})\end{array}$} \\
\hline Year & 2013 & 2014 & Pool & 2013 & 2014 & Pool & 2013 & 2014 & Pool & 2013 & 2014 & Pool & 2013 & 2014 \\
\hline $\mathbf{S}_{1}$ (River) & 1.0 & 1.6 & 1.3 & 0.7 & 0.3 & 0.5 & 0.02 & 0.06 & 0.04 & 0.01 & 0.01 & 0.01 & - & - \\
\hline $\mathbf{S}_{\mathbf{2}}$ (S.Ghat) & 0.19 & 0.13 & 0.16 & 0.2 & 00 & 0.1 & 0.01 & 0.05 & $\mathbf{0 . 0 3}$ & 00 & 00 & - & - & - \\
\hline $\mathrm{S}_{3}(\mathrm{C} . \mathrm{F})$ & - & - & - & - & - & - & - & - & - & - & - & - & - & - \\
\hline $\mathbf{S}_{4}($ H.Field $)$ & - & - & - & - & - & - & - & - & - & - & - & - & - & - \\
\hline $\mathbf{S}_{5}$ (Canteen) & - & - & - & - & - & - & - & - & - & - & - & - & - & - \\
\hline $\mathbf{S}_{6}(\mathrm{G.H})$ & - & - & - & - & - & - & - & - & - & - & - & - & - & - \\
\hline
\end{tabular}

Fig.1 pH of water samples collected from different selection sites

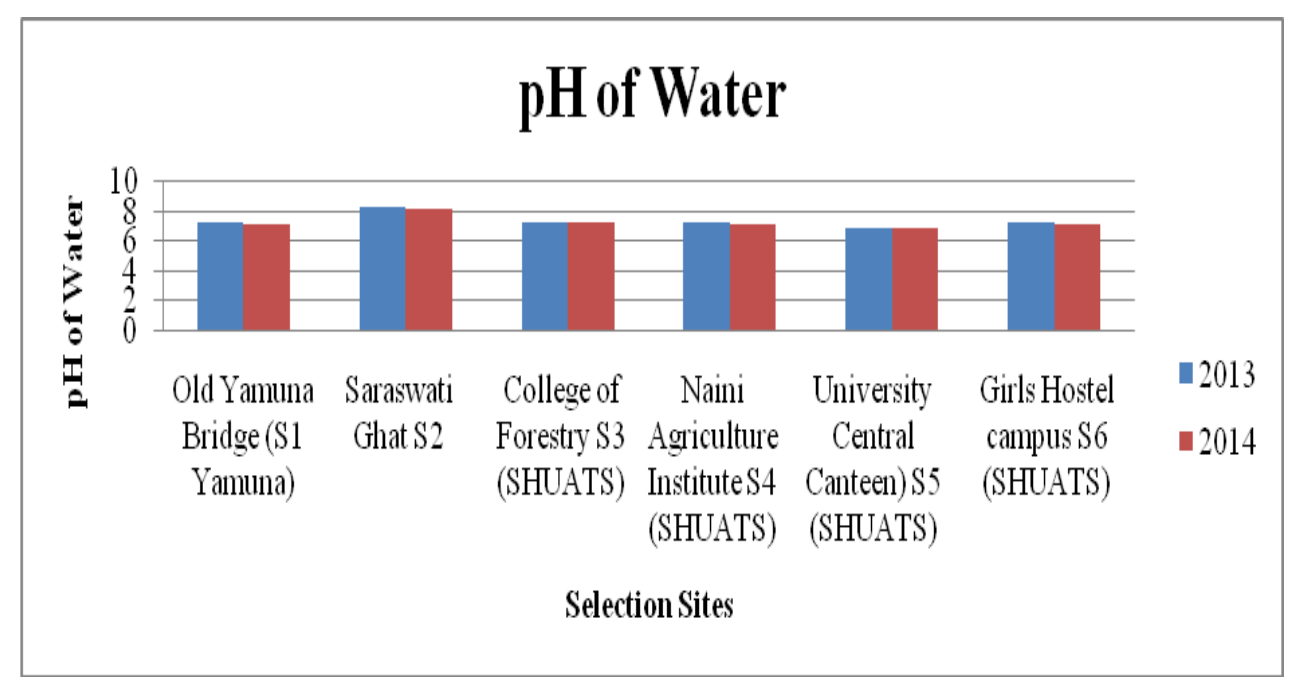


Fig.2 Level of electrical conductivity $(\mathrm{dS} / \mathrm{m})$ in different water samples

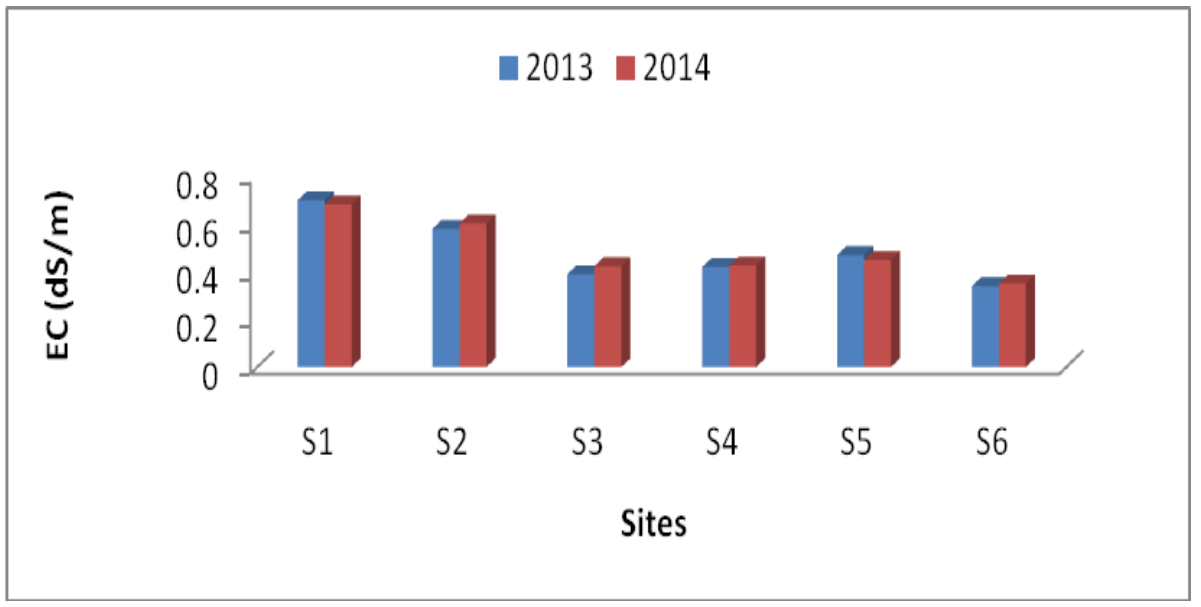

Fig.3 Availability of Nitrogen as Ammonia (ppm/L) in different water sample

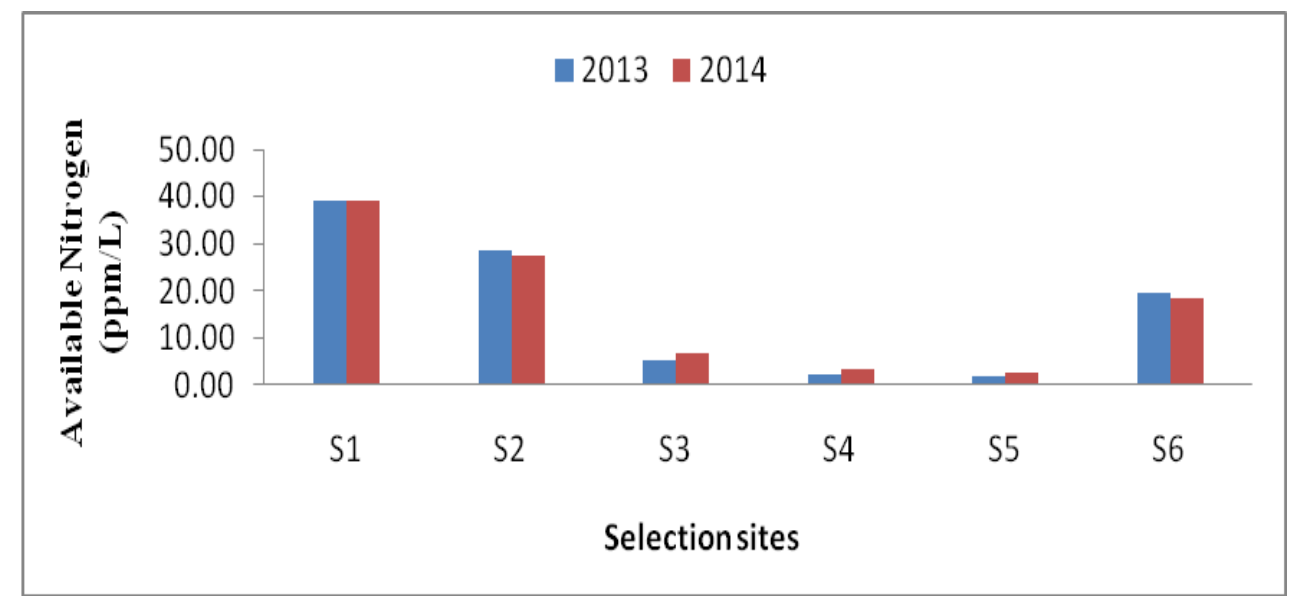

Fig.4 Availability of Nitrogen as Nitrate $\left(\mathrm{NO}_{2}\right)$ in different water sample

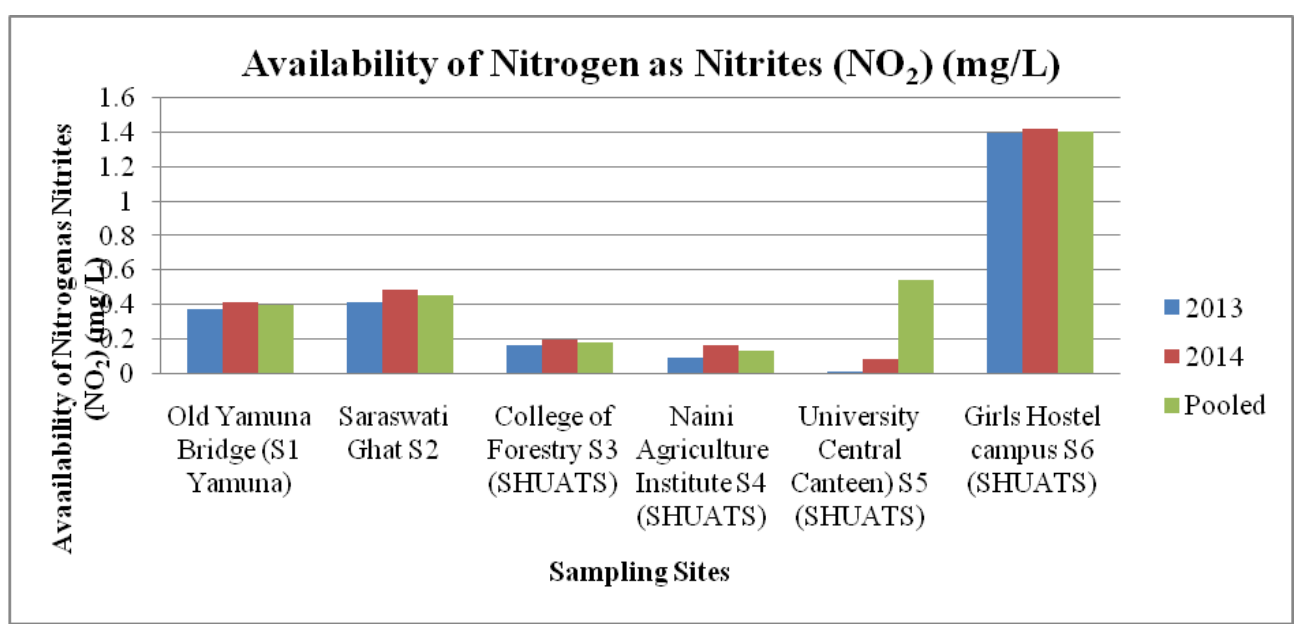


Fig.5 Availability of Phosphorus as Phosphate (mg/l) in different water sample

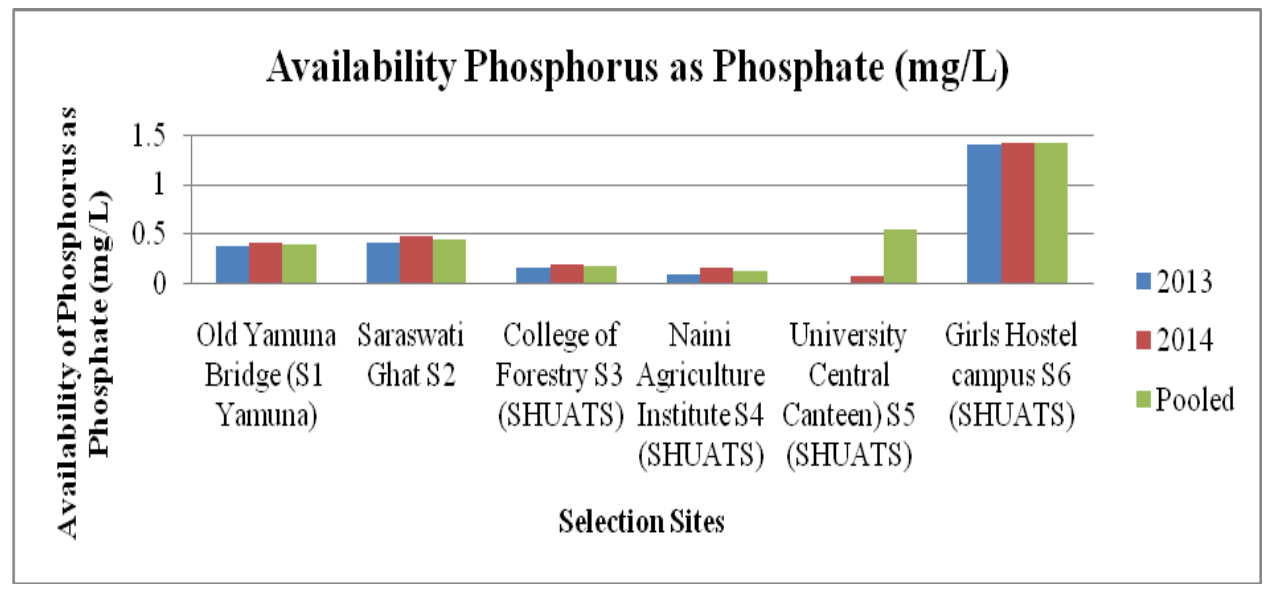

Fig.6 Level of Heavy metels (mg/l) in different water sample

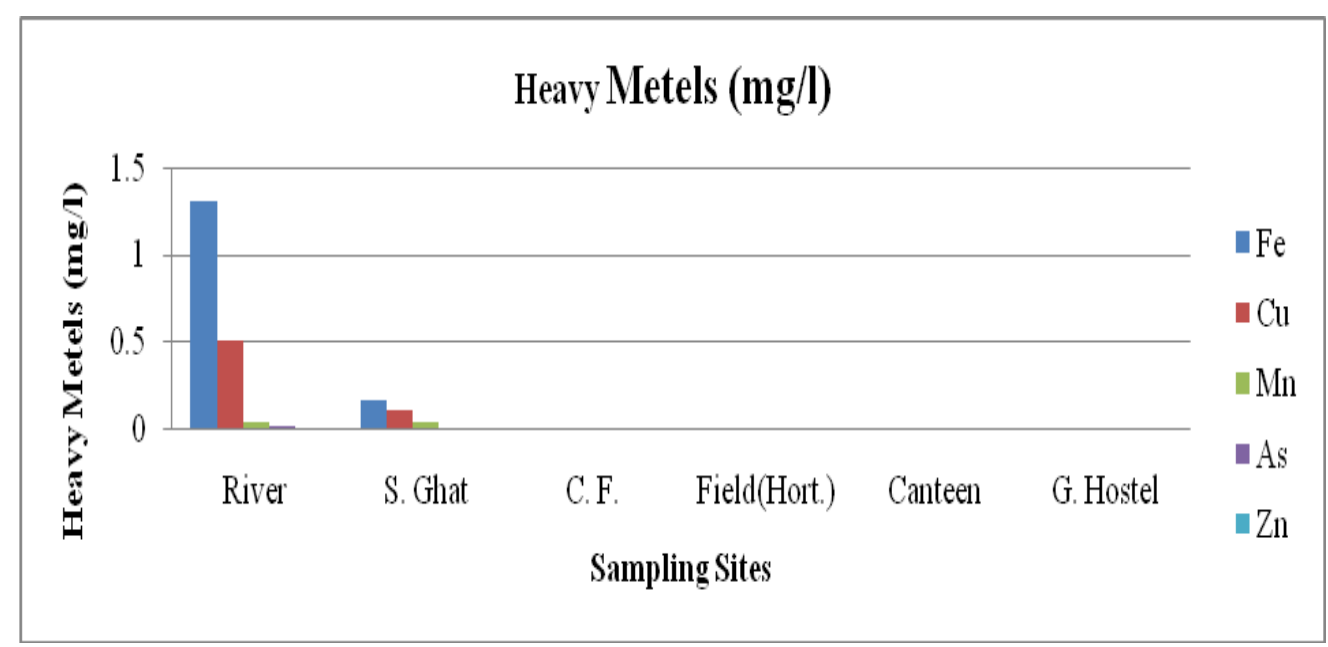

\section{Availability of Nitrogen as Ammonia $(\mathbf{p p m} / \mathrm{L})$}

Data presented in table 5 and figure 3 shows that the value of Ammonia in 2013 and in year 2014 is ranges between 1.8 to 39.2 and 2.56 to 39.26 respectively. Perusal of data also revealed that the Ammonium in exhibited positive and highly significant variation at different sampling sites in year 2013 and 2014. The maximum Ammonium in value was recorded at siteS 1 followed by siteS2 and site S6 whereas minimum value was found at siteS5 in the both year.

\section{Nitrogen as Nitrites $\left(\mathrm{NO}_{2}\right) \quad(\mathrm{mg} / \mathrm{l})$ at different sites}

Data presented in table 6 and figure 4 shows that the value of $\mathrm{NO}_{2}$ in the year 2013 and in year 2014 is ranges between 0.1 to 5.7 and 0.133 to 5.433 respectively. Perusal of data also revealed that the $\mathrm{NO}_{2}$ in exhibited positive and highly significant variation at different sampling sites in year 2013 and 2014. The maximum $\mathrm{NO}_{2}$ in value was recorded at siteS1 followed by site $\mathrm{S} 2$ and site S6 whereas minimum value was found at siteS3 in the both year. 
Data presented in table and figure shows that the value of $\mathrm{NO}_{2}$ in the year 2013 and in year 2014 is ranges between 0.1 to 5.7 and 0.133 to 5.433 respectively. Perusal of data also revealed that the $\mathrm{NO}_{2}$ in exhibited positive and highly significant variation at different sampling sites in year 2013 and 2014. The maximum $\mathrm{NO}_{2}$ in value was recorded at siteS 1 followed by siteS 2 and site S6 whereas minimum value was found at siteS3 in the both year.

\section{Available Phosphorus (mg/L) -}

Olsen colorimetric method (Olsen et al., 1954).According to Landon(1991), soils with Olsen phosphorus of less than 5 ppm are low, $5-15$ ppm $\mathrm{P}$ is medium and more than 15 ppm are high in available phosphorus. The values of available $P$ may be high in agricultural land due to the application of $\mathrm{P}$ fertilizer sources for a long time in vicinity of woodlands. Richards et al., (1995) and Juo et $a l .$, (1996) have also reported that application of $\mathrm{P}$ fertilizer would increase the available phosphorus forms. Data presented in table 7 and figure 5 shows that value of available phosphorus is ranges between 1.40 to 0.02 and 1.42 to 0.09 in 20132014 respectively and pool data varies from 1.41 to 0.40 and it is favourable for the growth of the blue green algae for all sampling sites. Perusal of data also revealed that the available phosphorus exhibited highly significant variation at different sites in year 2013 and 2014. The maximum available phosphorus was recorded at site 6 followed by site 2 and site1 (1) whereas minimum value was found at site 4 .

\section{Heavy metal (mg/l) analysis}

Heavy metals such as $\mathrm{Fe}, \mathrm{Cu}, \mathrm{Mn}$, As and $\mathrm{Zn}$ were determined by using AAS (Atomic Absorption Spectrophotometer) using standard reagents in $\mathrm{mg} / \mathrm{l}$. Heavy metals cause adverse effects in the living organisms mainly
$\mathrm{Pb}, \mathrm{Cu}, \mathrm{Cd}$, As. The heavy metals could not be detected in a sufficient amount in the samples that were located in the college campus, which could be measured in units i.e. they were found rarely in this area. The range of copper was found to be higher than the limits because it may cause adverse effect on consumption so, not suitable for drinking and domestic purposes. Arsenic was found in quite less quantity than the given permissible limit, so adverse effects are not expected (Table 8).

In conclusion the present study, it was observed that there was no significant variation in the occurrence and distribution of cyanobacteria and it was correlated with the physico-chemical parameters of water bodies. According to the ecobiological analysis revealed many dominant, co-dominant and ephimeral species from all the sample sites. The biological parameters showed that were was a site variation in the gross productivity compared to net productivity and community respiration rate in all the sampling sites.

\section{References}

Jeyachitra, K., A. Panneerselvam, R. Rajendran, M. Mahalakshmi, and S. Karthik Sundaram (2013): Physicochemical and biological factors in the distribution of cyanobacteria population in three different sampling sites of South India. Vol. 7(25), pp. 3240-3247, Academic Journals http://www.academicjournals.org/AJMR Matsuzaki M, JL Mucci, AA Rocha (2004). Phytoplankton community in a recreational fishing Lake, Brazil. Rev. Saude. Publica. 38:679-686.

Murty KSN, TSN Murty, P Venu, Seshavatharam (1986). Primary production in three fresh water bodies of Andhra Pradesh. Phykos, 25:68-74.

MuthukumarC, G Muralitharan, R 
Vijayakumar, A Panneerselvam, N Thajuddin (2007). Cyanobacterial biodiversity from different freshwater ponds of Thanjavur, Tamil Nadu (India). Acta Bot. Malacitana, 32:17-25. Pandey KD, SP Shukla, PN Shukla, DD Giri, JS Singh, P Singh, AK Kashyap (2004). Cyanobacteria in Antarctica: Ecology, physiology and cold adaptation. Cell Mol. Biol., 50:575-584.

Parikh A, V Shah, D Madamwar (2006).
Cyanobacterial flora from polluted industrial effluents. Environ. Monitor. Assess. 116:91-102.

Ravindra K, A Meenakshi, M Rani, A Kaushik (2003). Seasonal variations in physico-chemical characteristics of River Yamuna in Haryana and its ecological best-designated use. J. Environ. Monit., 5:419-426.

\section{How to cite this article:}

Ankita Lal and Suchit John. 2020. Occurrence and Abundance of Cyanobacterial Strains and Physico-chemical Properties of Water Bodies. Int.J.Curr.Microbiol.App.Sci. 9(10): 2193-2201. doi: https://doi.org/10.20546/ijcmas.2020.910.266 